\title{
Pim1 inhibition as a novel therapeutic strategy for Alzheimer's disease
}

Ramon Velazquez ${ }^{1}$, Darren M. Shaw ${ }^{1,2}$, Antonella Caccamo ${ }^{1}$ and Salvatore Oddo ${ }^{1,2^{*}}$ (i)

\begin{abstract}
Background: Alzheimer's disease (AD) is the most prevalent neurodegenerative disorder worldwide. Clinically, AD is characterized by impairments of memory and cognitive functions. Accumulation of amyloid- $\beta(A \beta)$ and neurofibrillary tangles are the prominent neuropathologies in patients with AD. Strong evidence indicates that an imbalance between production and degradation of key proteins contributes to the pathogenesis of AD. The mammalian target of rapamycin (mTOR) plays a key role in maintaining protein homeostasis as it regulates both protein synthesis and degradation. A key regulator of mTOR activity is the proline-rich AKT substrate $40 \mathrm{kDa}$ (PRAS40), which directly binds to mTOR and reduces its activity. Notably, AD patients have elevated levels of phosphorylated PRAS40, which correlate with A $\beta$ and tau pathologies as well as cognitive deficits. Physiologically, PRAS40 phosphorylation is regulated by Pim1, a protein kinase of the protoconcogene family. Here, we tested the effects of a selective Pim1 inhibitor (Pim1i), on spatial reference and working memory and AD-like pathology in 3xTg-AD mice.

Results: We have identified a Pim1i that crosses the blood brain barrier and reduces PRAS40 phosphorylation. Pim1i-treated 3xTg-AD mice performed significantly better than their vehicle treated counterparts as well as non-transgenic mice. Additionally, 3xTg-AD Pim1i-treated mice showed a reduction in soluble and insoluble $A \beta_{40}$ and $A \beta_{42}$ levels, as well as a $45.2 \%$ reduction in $A \beta_{42}$ plaques within the hippocampus. Furthermore, phosphorylated tau immunoreactivity was reduced in the hippocampus of Pim1i-treated 3xTg-AD mice by $38 \%$. Mechanistically, these changes were linked to a significant increase in proteasome activity.

Conclusion: These results suggest that reductions in phosphorylated PRAS40 levels via Pim1 inhibition reduce $A \beta$ and Tau pathology and rescue cognitive deficits by increasing proteasome function. Given that Pim1 inhibitors are already being tested in ongoing human clinical trials for cancer, the results presented here may open a new venue of drug discovery for $A D$ by developing more Pim1 inhibitors.
\end{abstract}

Keywords: AD, Pim1 inhibitor, PRAS40, 3xTg-AD, Proteasome, A $\beta$, tau, mTOR, Aging, Working memory

\section{Background}

Alzheimer's disease (AD) is the most prevalent neurodegenerative disorder worldwide. Clinically, AD is characterized by impairments of memory, cognitive and intellectual functions [1]. The buildup of amyloid- $\beta(A \beta)$ plaques and neurofibrillary tangles (NFTs) are the two prominent pathologies contributing to the progression of cognitive deficits in $\mathrm{AD}[2] . \mathrm{A} \beta$ is generated from the amyloid precursor protein (APP), which is sequentially cleaved by the $\beta$-site APP cleaving enzyme 1 (BACE-1)

\footnotetext{
* Correspondence: oddo@asu.edu

${ }^{1}$ Neurodegenerative Disease Research Center, Biodesign Institute, School of Life Sciences, Arizona State University, 727 E. Tyler Street, Tempe, AZ 85287-5001, USA

${ }^{2}$ School of Life Sciences, Arizona State University, Tempe, AZ 85287, USA
}

and the $\gamma$-secretase complex to liberate $A \beta$. NFTs consist of hyperphosphorylated and aggregated tau, a microtubule-binding protein. Over the next few decades, advancing age of the global population will dramatically increase the prevalence of $\mathrm{AD}$ to an estimated 20 million by 2050 in the US alone [3]. Currently, there are no effective treatment options to either prevent or reduce the progression of AD. Therefore, there is an urgent need for novel, safe, and efficacious strategies to mitigate this disorder.

Aging is the most important risk factor for AD; thus, it is possible that altered signaling pathways associated with aging may facilitate the development of $\mathrm{AD}$ and other age-dependent disorders $[4,5]$. Overwhelming evidence has shown that the mammalian target of 
rapamycin (mTOR), a serine/threonine protein kinase involved in the regulation of protein synthesis and degradation, plays a key role in regulating lifespan and health span [5-7]. mTOR is part of two major complexes, the mTOR complex 1 (mTORC1) and 2 (mTORC2), which have different functions $[8,9]$. mTOR signaling is upregulated in AD [10-13]. To this end, we and others have shown that reducing mTOR activity pharmacologically, with rapamycin, or genetically ameliorates $A \beta$ plaque load and NFTs while improving cognitive deficits in multiple animal models of $\mathrm{AD}[10,14-17]$. However, various studies have found that rapamycin has many side effects, necessitating other treatment options to reduce mTOR hyperactivity in $\mathrm{AD}$ [18-20].

The proline-rich Akt substrate $40 \mathrm{kDa}$ (PRAS40) is a constituent of the mTORC1, which physically binds to mTOR and inhibits its activity. Upon phosphorylation at Thr246 by serine/threonine-specific protein kinase (AKT) or proto-oncogene serine/threonine-protein kinase Pim-1 (Pim1), PRAS40 detaches from mTORC1 thereby releasing its inhibitory effects [21, 22]. We have shown that intrahippocampal injection of naturally secreted $A \beta$ is sufficient to increase mTOR signaling in the brains of wild type mice by increasing the phosphorylation of PRAS40 [23].

Pim1 is a kinase member of the proto-oncogene Pim kinase family [24-27]. Pim1 plays a role in cell survival and proliferation; hence, its deregulation can easily transform it to an oncogenic protein. Pim1 has gained much attention due to its upregulation in a variety of cancers $[28,29]$. Of note, Pim1 knockout mice have no phenotype [30], suggesting that Pim1 might be a viable therapeutic target. Crystallographic studies revealed a unique architecture within the Pim1 secondary structure, which allowed the synthesis of highly specific inhibitors [31, 32]. Here, we sought to determine the effects of reducing Pim 1 activity on AD-like pathology developed by the $3 x \mathrm{Tg}-\mathrm{AD}$ mice.

\section{Results}

\section{Pharmacological characterization of Pim1 inhibitor 1}

We have previously shown that the levels of PRAS40 phosphorylated at Thr246 (pPRAS40) are increased in $3 x \mathrm{Tg}-\mathrm{AD}$ mice [23]. To further determine the role of PRAS40 in AD, we assessed the levels of pPRAS40 in the inferior frontal gyrus of human AD brains (Table 1). We found that the levels of pPRAS40 are increased in human $\mathrm{AD}$ brains compared to age-matched controls (Fig. 1). We then sought to determine the effects of reducing PRAS40 phosphorylation on the AD-like pathology in 3xTg-AD mice. To achieve our goal, we targeted Pim1, a kinase known to phosphorylate PRAS40 [33]. Several Pim1 kinase inhibitors are commercially available,
Table 1 Descriptive information of patients whose brain tissue was utilized to measure pPRAS40 levels. Gel order indicates the order in which protein samples were loaded in Fig. 1

\begin{tabular}{|c|c|c|c|c|}
\hline Age at death & Diagnosis & MMSE score & Braak stage & Gel load order \\
\hline 86 & $A D$ & 16 & IV & 1 \\
\hline 82 & $A D$ & 23 & IV & 2 \\
\hline 93 & $C T L$ & 30 & । & 3 \\
\hline 89 & $C T L$ & 29 & $\|$ & 4 \\
\hline 92 & $C T L$ & 26 & III & 5 \\
\hline 79 & $C T L$ & 29 & $\|$ & 6 \\
\hline 82 & $A D$ & 19 & V & 7 \\
\hline 78 & $A D$ & 0 & $\mathrm{Vl}$ & 8 \\
\hline 87 & $C T L$ & 28 & III & 9 \\
\hline 91 & $C T L$ & 27 & ॥ & 10 \\
\hline 87 & $C T L$ & 26 & III & 11 \\
\hline 75 & $C T L$ & 29 & III & 12 \\
\hline 95 & $C T L$ & 26 & III & 13 \\
\hline 88 & $A D$ & 9 & $\mathrm{Vl}$ & 14 \\
\hline 78 & $A D$ & - & IV & 15 \\
\hline 68 & $A D$ & 0 & $\mathrm{VI}$ & 16 \\
\hline 78 & $C T L$ & 29 & III & 17 \\
\hline 85 & $A D$ & 23 & $\mathrm{Vl}$ & 18 \\
\hline 86 & $A D$ & 20 & IV & 19 \\
\hline
\end{tabular}

and some are currently in clinical trial for the treatment of cancer (ClinicalTrials.gov Identifier: NCT00848601). The commercially available Pim1 inhibitor, 3-Cyano-4-phenyl6-(3-bromo-6-hydroxy) phenyl-2 (1H)-pyridone (herein referred to as Pim1i; Fig. 2a), exhibits highly specific competitive inhibition to Pim1; $\mathrm{IC}_{50} 50 \mathrm{nM}$ for Pim1 and $2 \mu \mathrm{M}$ for Pim2 [33]. We have shown that intracranial delivery of this inhibitor effectively decreases pPRAS40 [23], a downstream substrate of Pim1. We first tested Pim1i bioavailability and measured its brain-to-plasma ratio by LC-MS/MS analysis. To this end, C57BL/6 mice received a single dose of $50 \mathrm{mg} / \mathrm{kg}$ Pimli intraperitoneally (i.p.). We found that maximum plasma concentration of Pimli was $32166 \pm 11220 \mathrm{ng} / \mathrm{mL}$, which was observed at $1 \mathrm{~h}$ post dose with half-life of $1.02 \mathrm{~h}$ (Fig. 2b). Pim1i was also detectable up to $3 \mathrm{~h}$ post dose in brain tissue homogenate samples (Fig. 2c). The maximum brain concentration of $197 \pm 48.5 \mathrm{ng} / \mathrm{g}$ was observed at $0.5 \mathrm{~h}$ post dose.

To determine whether Pim1i engages the target, we injected C57BL/6 mice with $100 \mathrm{mg} / \mathrm{kg}$ i.p. and harvested brains at $1,3,6,12$ and 24 post injection $(n=5$ per time-point). Three additional mice were used as our baseline. We decided to increase the dose as no toxicity was detected in mice receiving $50 \mathrm{mg} / \mathrm{kg}$ Pim1i. We found that the levels of pPRAS40 were significantly different across the different time points $\left(\mathrm{F}_{(6,26)}=11.09\right.$; $p<0.001$; Fig. 2d). A Bonferroni's multiple comparison 


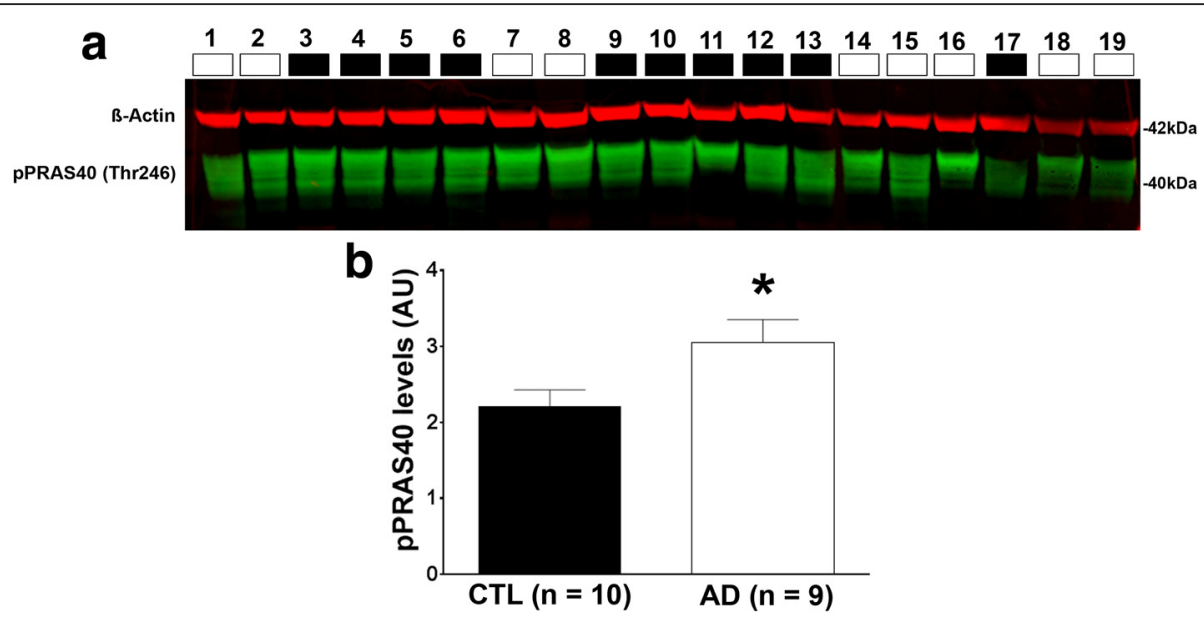

Fig. 1 Phosphorylated PRAS40 levels are increased in AD patients. a Western blots of proteins extracted from the inferior temporal gyrus of human control $(C T L ; n=10)$ and $A D$ brains $(n=9)$. Blots were probed with the indicated antibodies. The descriptive information for each patient (numbered above the blots) are reported in Table 1. b Quantitative analysis of the blot shows that phosphorylated PRAS40 levels were significantly higher in AD compared to CTL cases $(p=0.0325)$. Quantitative analyses of the blots were obtained by normalizing PRAS40 levels to $\beta$-Actin, used as a loading control. Error bars represent mean \pm SEM

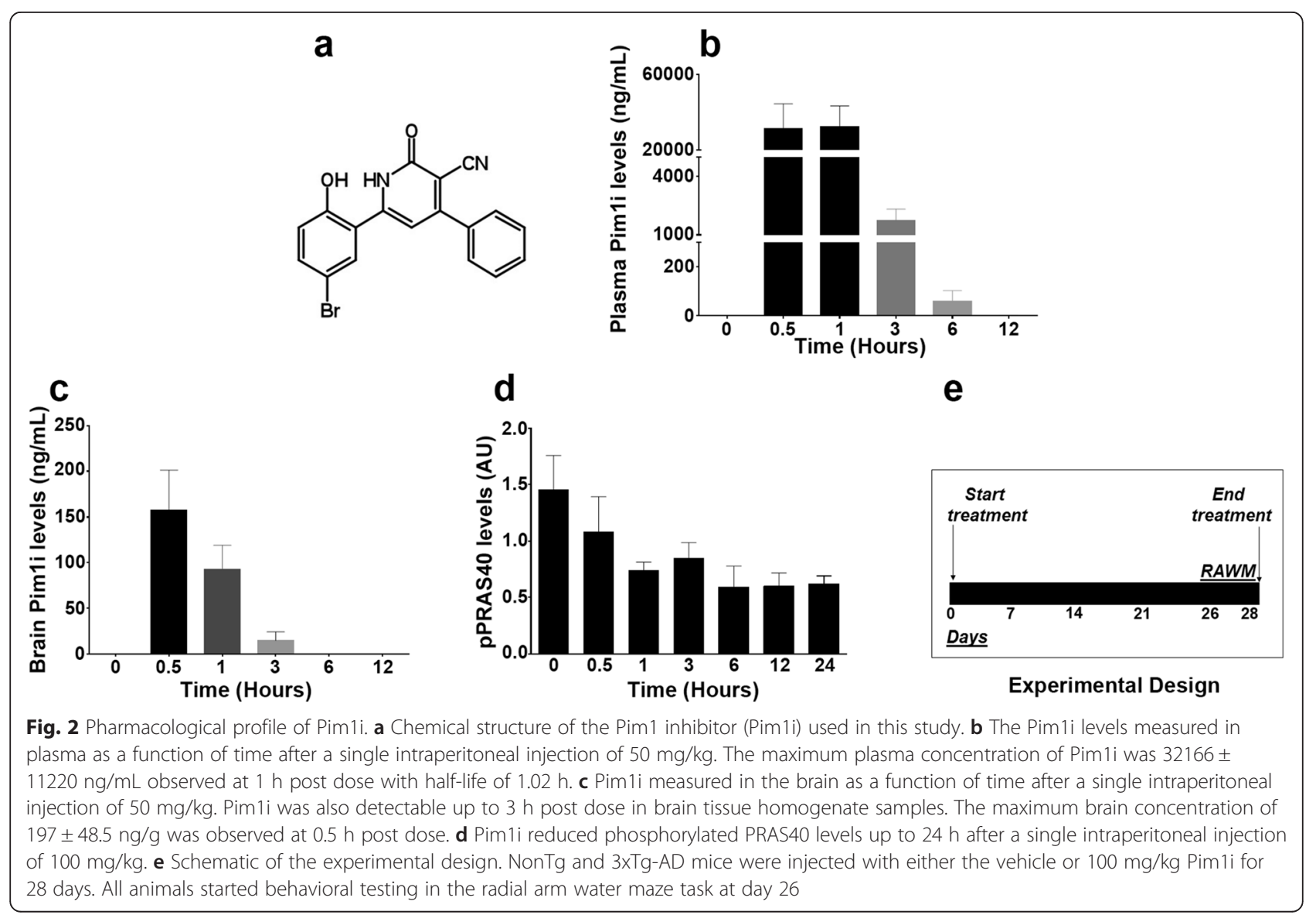


test indicated that pPRAS40 levels at the time points 1 , $3,6,12$ and $24 \mathrm{~h}$ were significantly different than time 0 , our baseline control. These data show that brain levels of pPRAS40 were significantly reduced one hour following the Pim1i injections and stayed low for $24 \mathrm{~h}$.

\section{Pim1 inhibition reduces spatial reference and working memory deficits in 3xTg-AD mice}

Given these data, we sought to determine the effects of chronic administration of the Pim1i at a dosage of $100 \mathrm{mg} / \mathrm{kg}$ on the AD-like pathology in 3xTg-AD mice. To this end, we used 7-month-old female 3xTg-AD and non-transgenic (NonTg) mice. At this age, 3xTg-AD mice have mild cognitive deficits, which are associated with high soluble $\mathrm{A} \beta$ and tau levels [34]. Mice were randomly assigned to one of the following groups: 3xTg-AD Vehicle (Veh), NonTg Veh, 3xTg-AD Pim1i, NonTg Pim1i ( $n=14$ /group) and received daily i.p. injections of Pim1i or vehicle for 28 days (Fig. 2e).

We first assessed body weight of the mice at the beginning of treatment and found that the average body weight was $24.21 \pm 0.635 \mathrm{~g}$ for NonTg mice and $31.46 \pm$ $1.427 \mathrm{~g}$ for $3 \mathrm{xTg}-\mathrm{AD}$ mice. The analysis of mean weight revealed a significant main effect of Genotype $\left(\mathrm{F}_{(1,42)}=\right.$ $36.624, p<0.0001)$, indicating that 3xTg-AD mice weighed significantly more than NonTg mice. Similarly, $3 x$ Tg-AD mice $(28.28 \pm 1.05 \mathrm{~g})$ weighed more than the NonTg mice $(22.48 \pm 0.46 \mathrm{~g})$ at completion of treatment. The analysis of mean weight in grams revealed a significant main effect of Genotype $\left(\mathrm{F}_{(1,42)}=28.689, p<\right.$ $0.0001)$ and Treatment $\left(\mathrm{F}_{(1,42)}=5.364, p<0.05\right)$, however no significant Genotype by Treatment interaction $\left(\mathrm{F}_{(1,42)}=1.117, p>0.05\right)$. Together, these data indicate that the Pim1i treated mice weighed less at the end of treatment compared to the mice on vehicle, and this difference was independent of genotype. Notably, during the 28 days of treatment, we lost mice in all four groups. The total numbers of mice that did not show any overt toxicity and were tested behaviorally are as follows: $3 x T g-A D$ Veh $(n=13)$, NonTg Veh $(n=12)$, 3xTg-AD Pim1i $(n=7)$, NonTg Pim1i $(n=13)$.

To determine the effect of 28 days of the Pim1i on spatial reference and working memory, we tested all subjects on an 8-arm radial arm water maze (RAWM) task. Mice were tested for two consecutive days: on day one, mice received 15 trials, with trials alternating between visible and hidden platform. On day 2, mice received 15 additional trials but the platform was kept hidden throughout the trials. Entry into an incorrect arm was scored as a spatial reference error. Reentry into a previously visited arm within the trial was considered a working memory error. The number of errors were averaged by block, with each block being equivalent to three trails. Using a mixed model ANOVA, we first examined mean incorrect errors between day 1 and 2 to assess learning. We found a significant effect of Genotype $\left(\mathrm{F}_{(1,42)}=\right.$ $13.610 ; p<0.01)$, Treatment $\left(\mathrm{F}_{(1,42)}=18.790, p<0.0001\right)$, day $\left(\mathrm{F}_{(1,42)}=107.868, p<0.0001\right)$ and a trend in Genotype by Treatment interaction $\left(\mathrm{F}_{(1,42)}=3.755, \quad p=0.0594\right.$; Fig. 3a). Specifically, all groups showed a significant reduction in incorrect errors between day 1 and day 2, indicating that all groups significantly learned the task.

We next analyzed the number of errors during the probe trials (day 2). For reference errors, we found a significant effect of Block $\left(\mathrm{F}_{(4,42)}=3.882, p<0.005\right.$, Fig. 3b), Genotype $\left(\mathrm{F}_{(1,42)}=8.126, p<0.01\right)$, Treatment $\left(\mathrm{F}_{(1,42)}=\right.$ $18.105, p<0.001)$ and a significant Genotype by Treatment interaction $\left(\mathrm{F}_{(1,42)}=4.496, p<0.05\right)$. Post hoc test with Bonferroni's correction indicated that 3xTg-AD Veh mice committed a higher number of reference errors throughout the 5 blocks of testing when compared to the NonTg Veh group ( $p<0.05$; Fig. 3b for errors across each block; $2 \mathrm{C}$ for mean total errors). Notably, 3xTg-AD Pim1i mice made significantly fewer errors compared to 3xTg-AD Veh treated mice, indicating improved spatial reference memory $(p<0.01)$. Furthermore, 3xTg-AD Pim1i mice performed as well as NonTg Veh mice $(p>0.05)$, illustrating a full rescue of spatial reference memory. Interestingly, NonTg mice injected with Pim1i made significantly fewer errors than the vehicle treated NonTg mice $(p<0.05)$. These results show that 28 days of Pim1i administration is sufficient to normalize the spatial reference memory deficits in $3 x \mathrm{Tg}-\mathrm{AD}$ mice to NonTg levels, and to improve performance in NonTg mice.

We then examined reentry errors into a previously entered arm within a trial, which indicate working memory errors. When we compared the mice performance between the two days of training, we found a significant effect of Genotype $\left(\mathrm{F}_{(1,42)}=8.045, p=0.01\right)$, Treatment $\left(\mathrm{F}_{(1,42)}=\right.$ $10.381, p<0.01)$, day $\left(\mathrm{F}_{(1,42)}=13.693, p<0.001\right)$, and a Genotype by Treatment interaction $\left(\mathrm{F}_{(1,42)}=4.390, p<\right.$ 0.05; Fig. 3d). Notably, 3xTg-AD Veh mice had the same number of working memory errors between day 1 and day $2(p>0.05)$, indicating that although they decreased the number of reference memory errors, they continued to commit working memory errors on day 2 . All other groups show a decrease in working memory errors between day 1 and day 2. These data indicate that 3xTg-AD Pim 1i mice performed significantly fewer working memory errors compared to $3 \mathrm{xTg}-\mathrm{AD}$ Veh. During the probe trials (day $2)$, we found a significant effect of Genotype $\left(\mathrm{F}_{(1,42)}=\right.$ $5.255, p<0.05)$, Treatment $\left(\mathrm{F}_{(1,42)}=10.131, p<0.01\right)$, and Genotype by Treatment interaction $\left(\mathrm{F}_{(1,42)}=4.496, p<\right.$ 0.05; Fig. 3e). Post hoc test with Bonferroni's correction indicated that 3xTg-AD Veh mice committed a higher number of working memory errors throughout the 5 blocks of testing when compared to the NonTg-AD Veh mice $(p=0.0147$, Fig. 3e for errors across each block; $3 f$ for 


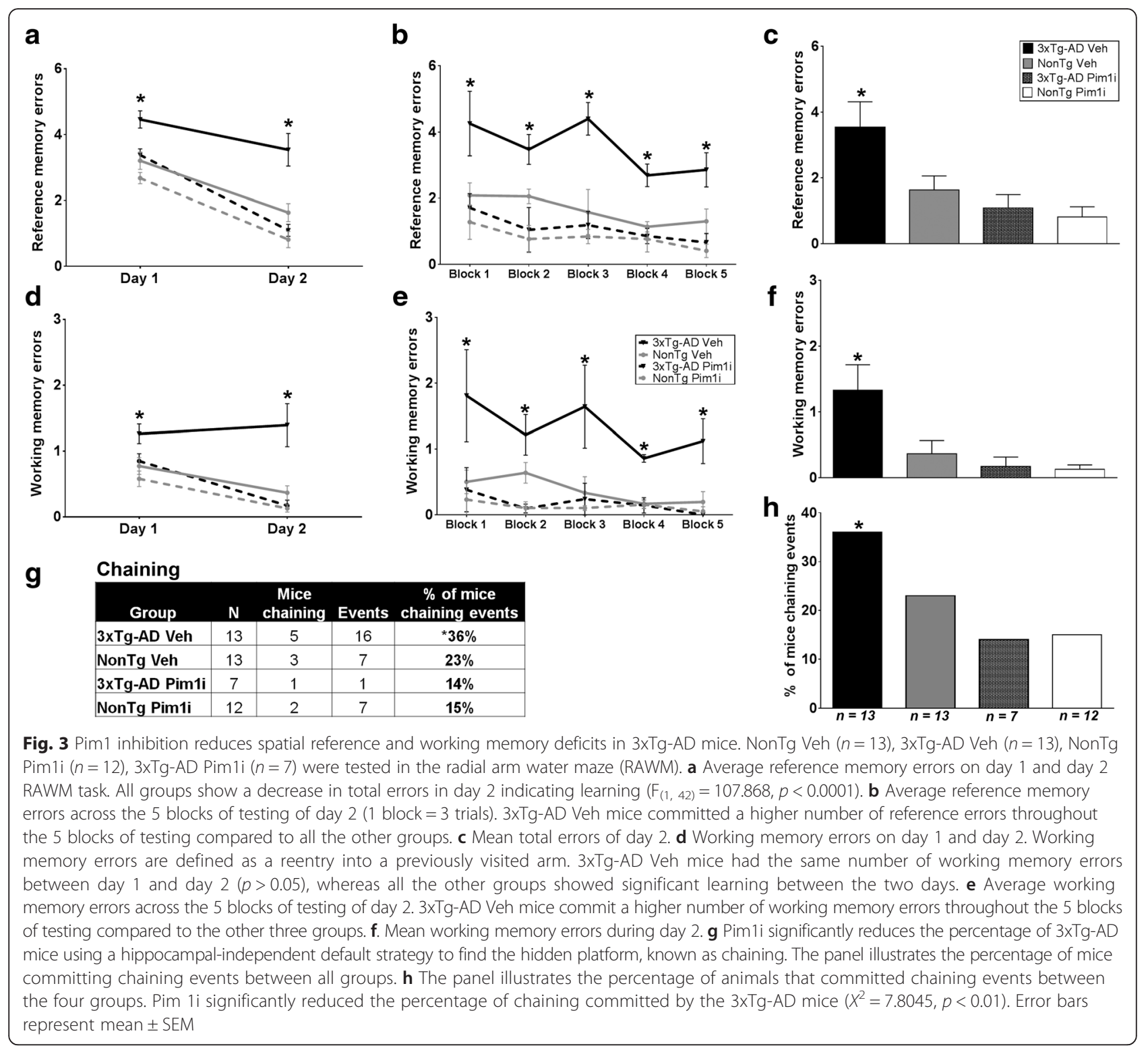

mean total errors). Pim1i significantly reduced the number of working memory errors in 3xTg-AD mice compared to $3 \mathrm{xTg}-\mathrm{AD}$ Veh mice $(p<0.05)$. Indeed, the number of working memory errors made by 3xTg-AD Pim1i mice were not statistically significant from errors made by NonTg Veh mice $(p>0.05)$. Collectively, these results show that 28 days of the Pim1 inhibitor is sufficient to reduce spatial reference and working memory deficits in 3xTg-AD mice.

"Chaining" is a commonly used search strategy to find the platform in the RAWM [35]. This method does not require use of spatial cues and instead consists of sequential arm visits until the platform is found. To further determine the nature of the cognitive impairment in 3xTg-AD mice, we examined the use of a chaining strategy for navigation of the maze during the day 2 probe trials. For this analysis, a chaining event was defined as three consecutive arm entries in an anticlockwise or clockwise direction, an operational definition used by [35]. The percentage of chaining events committed per group were analyzed using a chi-square test. We found that 3xTg-AD Veh mice show a significantly higher number of chaining events compared to both NonTg groups and 3xTg-AD Pim1i treated group $\left(X^{2}=7.8045, p<0.01\right.$, Fig. 3g-h). These data suggest that Pim1 inhibition reduces the usage of the chaining search strategy in 3xTg-AD mice.

Pim1 inhibition lowers $A \beta$ levels and hippocampal CP13 immunoreactivity in 3xTg-AD mice

At the end of the behavioral testing, mice were sacrificed and their brains were used for neuropathological and 
biochemical assessment. To determine whether peripheral administration of Pim1i reached the brain, we used sandwich enzyme linked immunosorbent assay to measure the levels of pPRAS40 at Thr246, as this epitope is directly phosphorylated by Pim 1 [33]. We found a significant effect for Genotype $\left(\mathrm{F}_{(1,20)}=4.501, p<0.05\right)$, Treatment $\left(\mathrm{F}_{(1,20)}=36.593, p<0.0001\right)$, and a nonsignificant Genotype by Treatment interaction $\left(\mathrm{F}_{(1,20)}=\right.$ 1.767, $p>0.05$; Fig. 4a). The effect of genotype indicated that $3 x \operatorname{Tg}$-AD mice show higher levels of pPRAS40 than NonTg mice. Interestingly, the treatment effect reveals that both 3xTg-AD and NonTg Pim1i mice have a reduced pPRAS40 level. Together, these data further confirm that Pim1i crosses the blood brain barrier and decreases the levels of brain pPRAS40.

One of the key neuropathological features of $\mathrm{AD}$ is the accumulation of extracellular $A \beta$ plaques [2]. $A \beta$ peptides consist of 36-43 amino acids, where $A \beta_{40}$ and $A \beta_{42}$ are the more abundant $A \beta$ species. $A \beta_{42}$ is more prone to aggregation and toxicity than the $A \beta_{40}$ species [2]. We immunostained sections from $3 \times \mathrm{Tg}-\mathrm{AD}$ Veh $(n=6)$ and $3 x T g-A D$ Pim1i $(n=5)$ mice with an $\mathrm{A} \beta_{42}$-specific antibody and found that $A \beta_{42}$ immunoreactivity was significantly reduced in the brains of $3 \times \mathrm{Tg}-\mathrm{AD}$ mice injected with Pim1i (Fig. 4b-c). Quantitative analysis of the overall
$\mathrm{A} \beta_{42}$ load indicated a significant decrease of $45.2 \%$ in the brain of 3xTg-AD Pim1i compared with 3xTg-AD mice $\left(t_{(10)}=8.419, p<0.05\right.$; Fig. $\left.4 d\right)$. We next measured $A \beta$ levels by sandwich ELISA and found that both soluble and insoluble $A \beta_{40}$ levels were significantly lower in 3xTg-AD Pim1i mice compared with 3xTg-AD Veh mice (soluble $A \beta_{40}: t_{(10)}=2.442, p<0.05$; insoluble $\mathrm{A} \beta_{40}: t_{(10)}=2.681, p=0.0230$; Fig. 5a-b). Furthermore, both soluble and insoluble levels of $A \beta_{42}$ were significantly lower in $3 x T g-A D$ Pim1i compared to $3 x T g-A D$ Veh mice (soluble $A \beta_{42}: t_{(10)}=2.404, p=0.0371$; insoluble $A \beta_{42}: t_{(10)}=3.932, p<0.01$; Fig. $5 \mathrm{c}-\mathrm{d}$ ).

Another hallmark pathology associated with $\mathrm{AD}$ is the accumulation of neurofibrillary tangles made of hyperphosphorylated tau [2]. To determine the effects of Pim1 inhibition on tau pathology, we first immunostained sections from 3xTg-AD Veh and 3xTg-Pim1-inh1 mice with $\mathrm{CP} 13$, an antibody that recognizes tau phosphorylated at serine 202. We found that CP13 immunoreactivity was reduced in 3xTg-AD Pim1i compared with 3xTg-AD mice (Fig. 6a-b). Quantitative analysis indicated that CP13 immunoreactivity was significantly decreased by $38 \%$ in the brain of 3xTg-AD Pim1i compared with 3xTg-AD Veh mice $\left(t_{(10)}=2.785, p<0.05\right.$; Fig. $\left.6 \mathrm{c}\right)$. To further assess the tau pathology, we measured tau levels by western blot

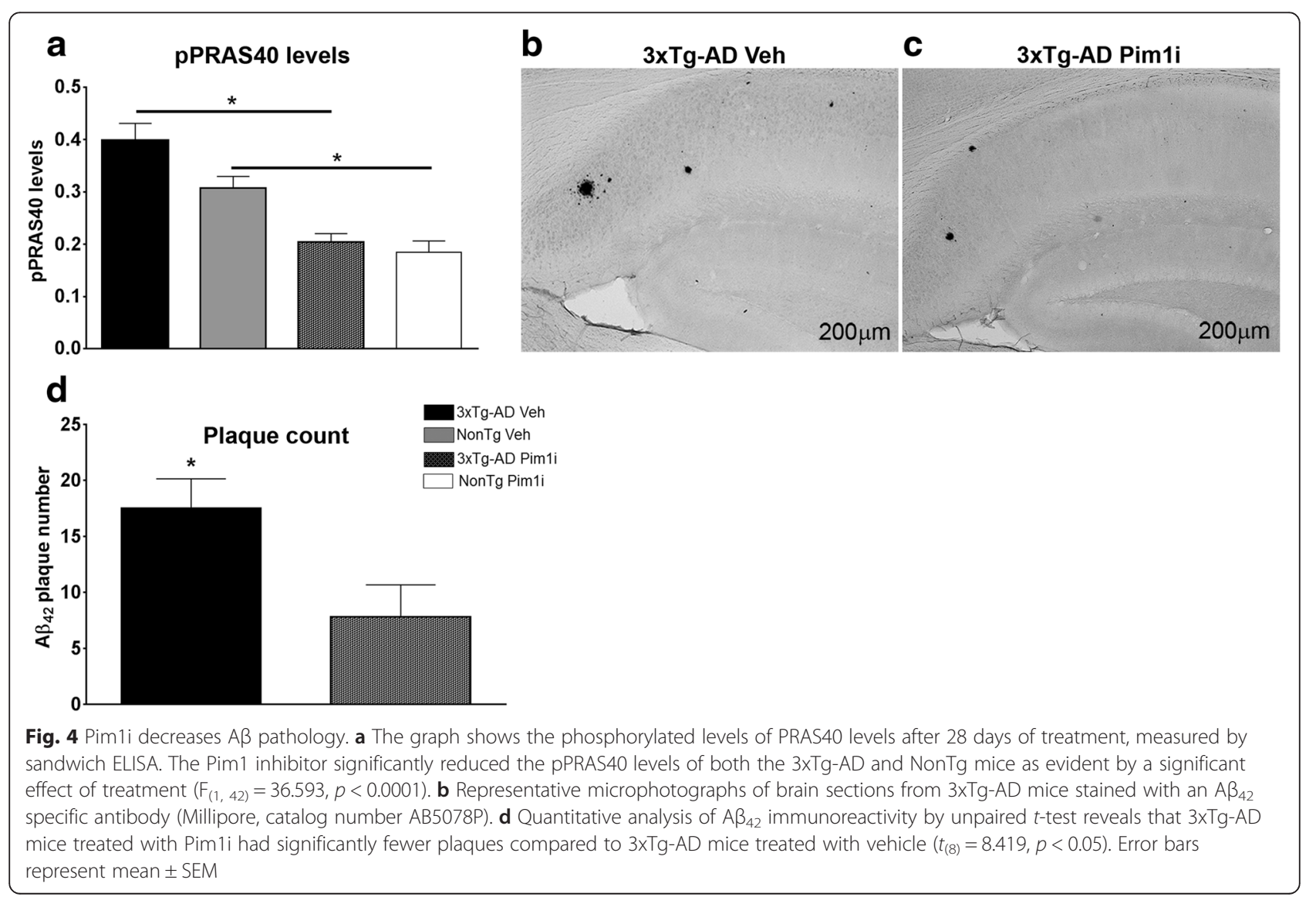


a

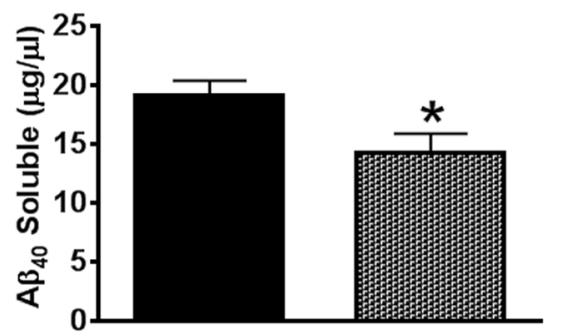

b

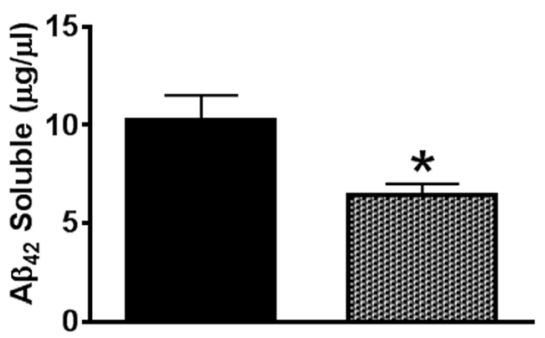

- 3xTg-AD Veh

- 3xTg-AD Pim1i

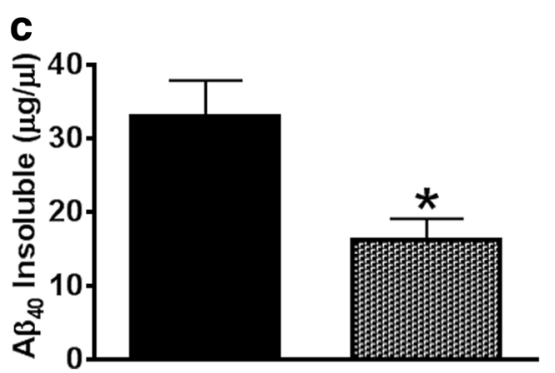

d

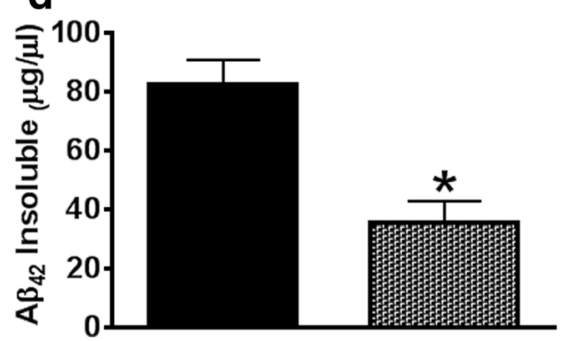

Fig. 5 Pim1i decreases $A \beta$ levels. Sandwich ELISA measurements of insoluble and soluble $A \beta_{40}$ and $A \beta_{42}$ levels in brain extracts from $3 x T$ - $A D$ veh $(n=7)$ and $3 x \operatorname{Tg}-A D$ Pim1i $(n=5)$ mice. $\mathbf{a}$, b Soluble and insoluble A 342 levels were significantly lower in $3 \times 19-A D$ mice injected with Pim1i (Soluble $A \beta_{40}: t_{(10)}=2.442, p<0.05$; insoluble $A \beta_{40}: t_{(10)}=2.681, p<0.05$ ). $\mathbf{c}$, d Soluble and insoluble $A \beta_{42}$ levels were significantly lower in 3xTg-AD mice treated with Pim1i (soluble $A \beta_{42}: t_{(10)}=2.404, p<0.05$; insoluble $A \beta_{42}: t_{(10)}=3.932, p<0.01$ ). Error bars represent mean \pm SEM

using antibodies against total and phosphorylated tau. We found that the levels of total human tau (measured by HT7) were not significantly different between the Veh and Pim1i-treated groups $(p>0.05$; Fig. 6d-e). In contrast, we found a main effect of Genotype for CP13 levels $\left(F_{(1,15)}=\right.$ 4.563, $p<0.05$; Fig. $6 \mathrm{~d}, \mathrm{f})$. Post hoc analyses indicated that $3 x T g-A D$ mice had significantly higher levels than NonTg mice. The apparent contradiction between the CP13 data obtained by immunohistochemistry and by western blot is likely due to the fact that the immunohistochemistry allows for single cell resolution while the western blot was done by homogenizing different cell types from different brain regions. Overall, these results show that Pim1 inhibition reduces hippocampal tau immunoreactivity in 3xTgAD mice.

\section{Pim1i increases proteasome activity}

Our results indicate that reductions in pPRAS40 via Pim1 inhibition is sufficient to reduce spatial reference and working memory deficits in 3xTg-AD mice. These improvements in cognitive function are associated with a reduction in $A \beta$ levels and phosphorylated tau immunoreactivity. To better elucidate the mechanisms underlying these effects, we first assessed mTOR signaling by measuring the phosphorylation levels of the two major downstream targets of mTOR: p70S6K1 and 4EBP1.
For the phosphorylation levels of p70S6K1, there were no significant effects of Genotype $\left(\mathrm{F}_{(1,15)}=4.067, p>\right.$ $0.05)$, treatment $\left(\mathrm{F}_{(1,15)}=0.428, p>0.05\right)$, and Genotype by Treatment interaction $\left(\mathrm{F}_{(1,15)}=1.831, p>0.05\right.$; Fig. 7a-b). Interestingly for the downstream target 4EBP1, there was a main effect of Genotype $\left(\mathrm{F}_{(1,15)}=5.621, \quad p=0.05\right.$; Fig. $7 \mathrm{a}, \mathrm{c})$ where the NonTg mice had increased levels of phosphorylated 4EBP1 compared to 3xTg-AD mice. There was no effect of the Pim1i treatment on these targets.

To further understand what mechanisms may underlie changes in AD pathology and improvements in behavior, we assessed autophagy induction and proteasome function. We focused on these systems as they represent the two major cellular protein degradation systems and are known to be involved in the turnover of $A \beta$ and tau [36]. First, we measured the levels of LC3, Atg3, Atg5, and Atg12, key proteins involved in autophagy induction whose levels are routinely used to monitor it [37]. We found a significant main effect of Genotype $\left(F_{(1,15)}=\right.$ $7.238, p<0.05)$ but a non-significant effect of Treatment $\left(\mathrm{F}_{(1,15)}=2.230, p>0.05\right)$ or Genotype by Treatment interaction $\left(\mathrm{F}_{(1,15)}=0.00042, p>0.05\right)$ for p62 (Fig. 8a-b). In addition, we found a significant main effect of Genotype $\left(\mathrm{F}_{(1,15)}=10.851, p<0.01\right)$ but a non-significant effect of Treatment $\left(\mathrm{F}_{(1,15)}=0.266, p>0.05\right)$ and the Genotype by 

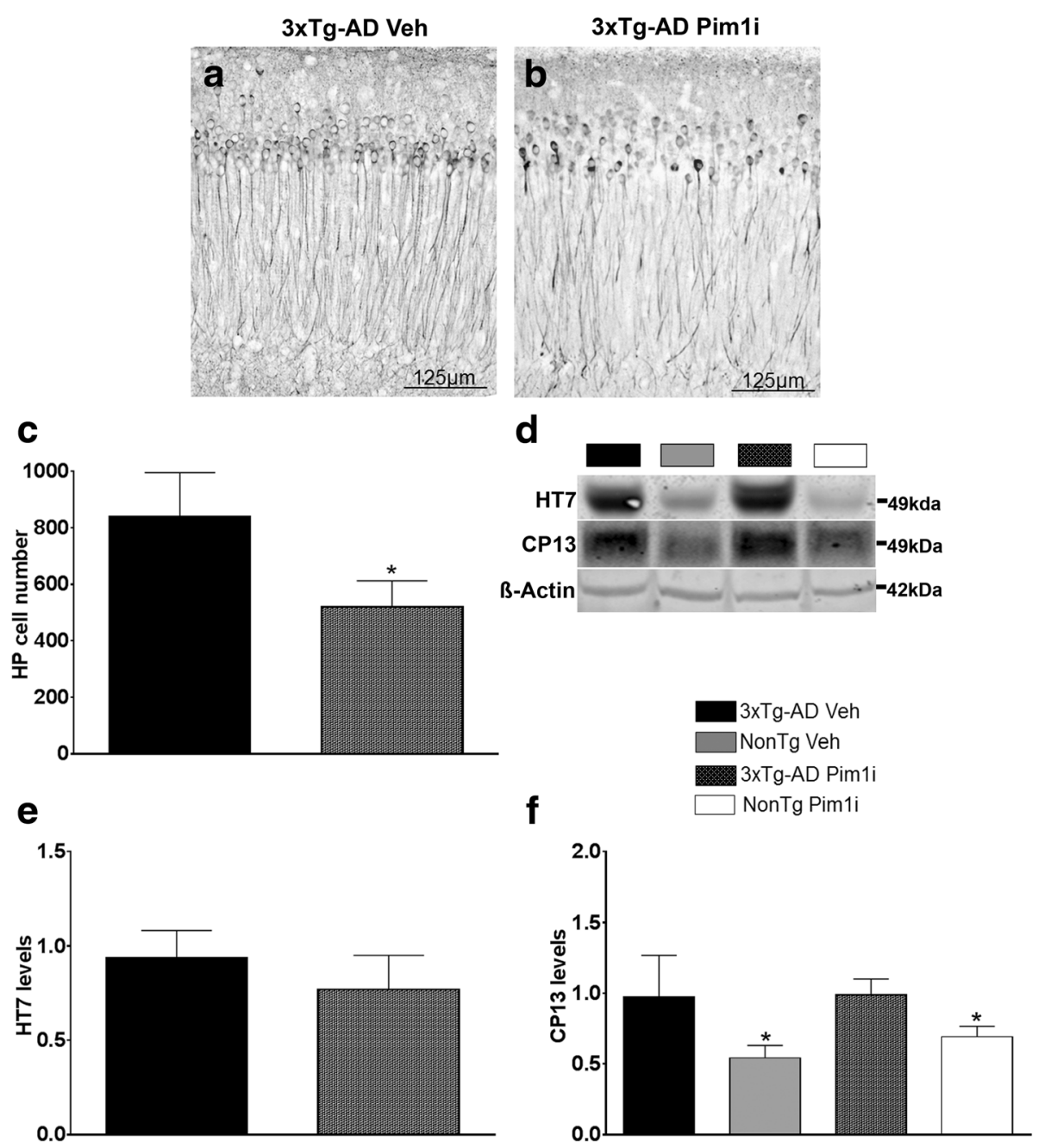

Fig. 6 Reduced Tau pathology in 3xTg-AD Pim1i mice. $\mathbf{a}$, b Representative microphotographs of CA1 hippocampal neurons from 3xTg-AD Veh and 3xTg-AD Pim1i mice stained with the anti-tau antibody CP13, which recognizes tau phosphorylated at Ser202. c Quantitative analysis of the CP13 immunoreactivity by unpaired $t$-test reveals that Pim1i significantly reduced tau immunoreactivity $\left(t_{(9)}=2.785, p<0.05\right)$. d Representative western blots of protein extracted from 3xTg-AD Veh, NonTg Veh, 3xTg-AD Pim1i, and NonTg Pim1i mice. Blots were probed with the indicated antibodies. The HT7 antibody recognizes total human tau and CP13 antibody recognizes tau phosphorylated at Ser202. e, f Quantitative analyses of the blots. HT7 levels were not significantly different between the two groups $\left(\mathrm{t}_{(9)}=0.558, p>0.05\right)$. For CP13, we found a Genotype effect $\left(t_{(9)}=4.563, p<0.05\right)$, revealing higher levels of CP13 in 3xTg-AD mice. Quantitative analyses of the blots were obtained by normalizing the levels of the protein of interest to $\beta$-Actin, used as a loading control. Error bars represent mean \pm SEM

Treatment interaction $\left(\mathrm{F}_{(1,15)}=1.607, p>0.05\right)$ for Atg3 (Fig. 8a, c). In contrast, the levels of Atg5 and Atg12 were similar among the four groups (Fig. 8a, d and e). Next, we used the fluorogenic substrates Bz-VGRAMC, Suc-LLVYAMC, and Z-LLE-AMC to measure trypsin-like, chymotrypsin-like, and caspase-like activities of the proteasome. We found an effect of Treatment for chymotrypsin-like $\left(\mathrm{F}_{(1,20)}=10.127, p<0.05\right.$, Fig. 8f), trypsin-like $\left(\mathrm{F}_{(1,20)}=16.18, p<0.001\right.$, Fig. $\left.8 \mathrm{~g}\right)$ and caspase-like $\left(\mathrm{F}_{(1,20)}=19.804, p<0.001\right.$, Fig. 8h) activity. This finding indicates that the Pim1 inhibitor increases the activity of the three substrates for both the 3xTg-AD and NonTg mice over the vehicle treated groups. This suggests that the reductions in A $\beta$ pathology and tau immunoreactivity may be accomplished by an increase in protein degradation.

\section{Discussion}

The incidence of $\mathrm{AD}$ is quickly increasing and with no effective therapeutics to reduce the associated pathologies, this disorder is bound to have a major socio-economic impact on our society. The data presented here unambiguously show that inhibiting Pim1 activity for 28 days, thereby reducing pPRAS40 levels, has beneficial effects on AD-like pathology in $3 \times T g-A D$ mice. Indeed, these data show that 


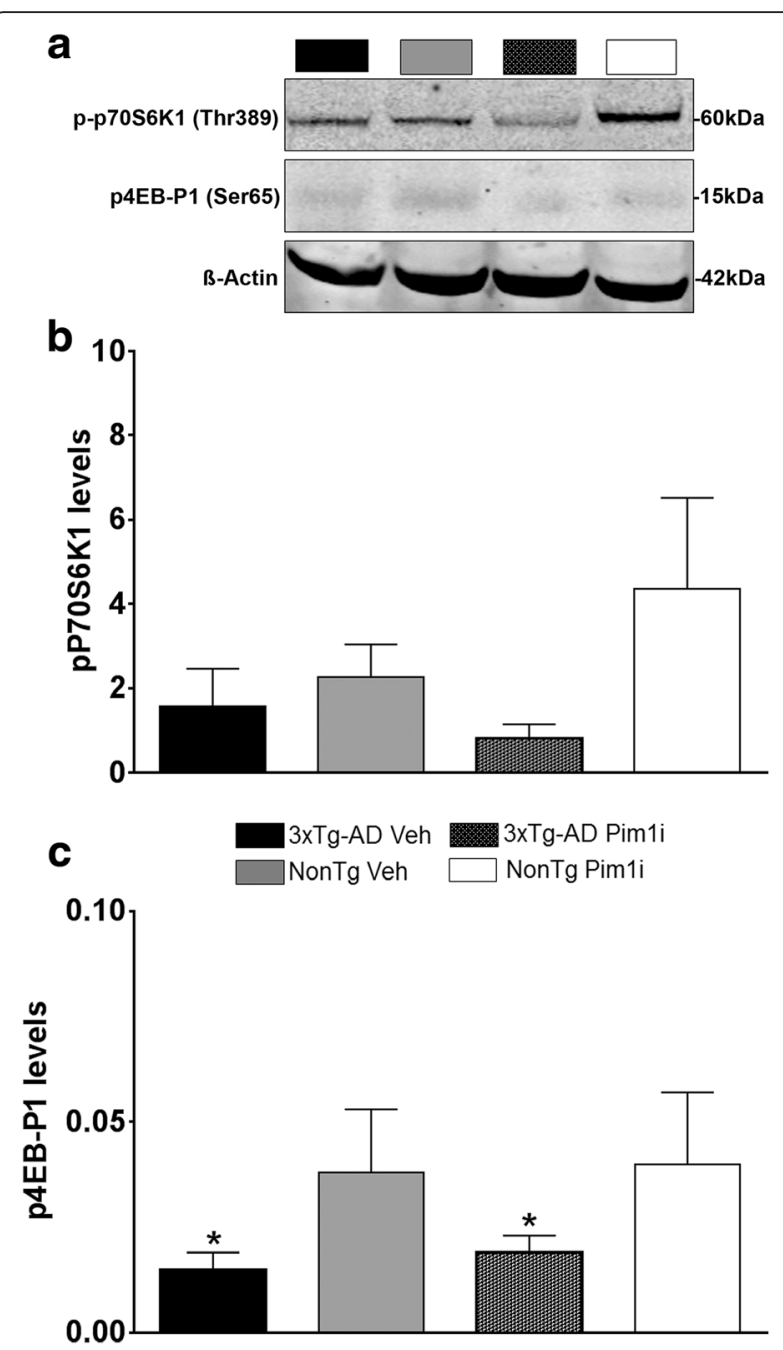

Fig. 7 Pim 1i does not alter mTORC1 signaling. a Representative western blots of the phosphorylated levels of downstream mTORC1 targets 4EB-P1, p70S6K1 and $\beta$-Actin control. b, c Quantitative analyses of the blots show. We found no changes in p-p70s6K1 levels. In contrast, we found that the NonTg groups had higher levels of p4EBP1 compared to the 3xTg-AD groups $\left(F_{(1,15)}=5.621, p<0.05\right)$. Quantitative analyses of the blots were obtained by normalizing the levels of the protein of interest to $\beta$-Actin, used as a loading control. Error bars represent mean \pm SEM

inhibition of Pim1 reduced spatial reference and working memory errors in 3xTg-AD mice, and improved performance to NonTg levels. This cognitive improvement was associated with a reduction in hippocampal $A \beta$ pathology and hippocampal tau immunoreactivity.

PRAS40 is a component of the mTOR complex 1 ; it physically binds to $\mathrm{mTOR}$ and negatively regulates its activity [33]. Upon phosphorylation, PRAS40 detaches from mTOR releasing its inhibitory effects. Indeed, high levels of pPRAS40 have been associated with high mTOR activity $[8,33]$. Notably, the levels of pPRAS40 are elevated in both humans $\mathrm{AD}$ patients and 3xTg-AD mice [23]. We have previously shown that the increase in pPRAS40 is due to a buildup in A $\beta$ oligomers [23]. Paradoxically, although we show that Pim1 inhibition reduces the levels of pPRAS40, the activity of mTOR appeared unaffected. Indeed, Pim1 inhibition did not change the phosphorylation levels of p70S6K1 and $4 \mathrm{EBP} 1$. These findings suggest that the reduction in $\mathrm{A} \beta$ pathology and hippocampal tau immunoreactivity may occur through an mTOR independent pathway. To this end, our data suggest that the mechanism underlying the reduced $\mathrm{AD}$-like pathology is linked to an increase in proteasome activity as evident by the changes in the three proteolytic activities, chymotrypsin-like, trypsinlike and caspase-like, which comprise the catalytic core of the proteasome [38-40]. These results are consistent with previous findings showing that modulation of pPRAS40 levels alter proteasome function independent of mTOR activity [41, 42].

Interestingly, the increase in three proteolytic activities of the proteasome were observed in both the 3xTg-AD and NonTg mice and were associated with inhibition of Pim1 and reduced pPRAS40 levels. The increase in proteasome activity suggests an increase in degradation of $\mathrm{A} \beta$ and tau proteins. Proteasome dysfunction has been linked to $\mathrm{AD}$ pathology in both $\mathrm{AD}$ patients and mouse models [43-45]. In particular, studies have shown that proteasome activity is decreased in the hippocampus, which is more susceptible to AD pathology, and less in areas like the cerebellum, where minimal to no changes in proteasome functions have been detected in $\mathrm{AD}$ patients [43]. To this end, work has found accumulation of $\mathrm{A} \beta$ and tau after direct inhibition of proteasome activity in the 3xTg-AD mice [45]. Consistent with these observations, we and others have reported that increased proteasome activity is sufficient to degrade $A \beta$ and relieve deficits in cognitive function [44, 46, 47].

Diabetes is a major risk factor of AD [48-50]; however, the molecular pathways linking diabetes to $\mathrm{AD}$ remain elusive. Physiologically, PRAS40 is activated by Pim1 and by phosphatidylinositol 3-kinase/Akt (PI3K/Akt), which are further regulated by upstream tyrosine kinase receptor growth factors, including insulin-like growth factor 1 [51]. To this end, insulin signaling facilitates PRAS40 phosphorylation at Thr246 [9, 52, 53]. Glucoseinduced hyperphosphorylation of PRAS40 has been implicated in type 2 diabetes [54] and in the progression of diabetic nephropathy [55]. Higher pPRAS40 levels increase activation of mTORC1 and its downstream targets [33]. At the same time, both PRAS40 phosphorylation and mTOR activity are increased in AD patients and in $\mathrm{AD}$ animal models, and contribute to the buildup of $A \beta$ and tau $[6,10,15,56]$. While further studies are needed, these data suggest that PRAS40 


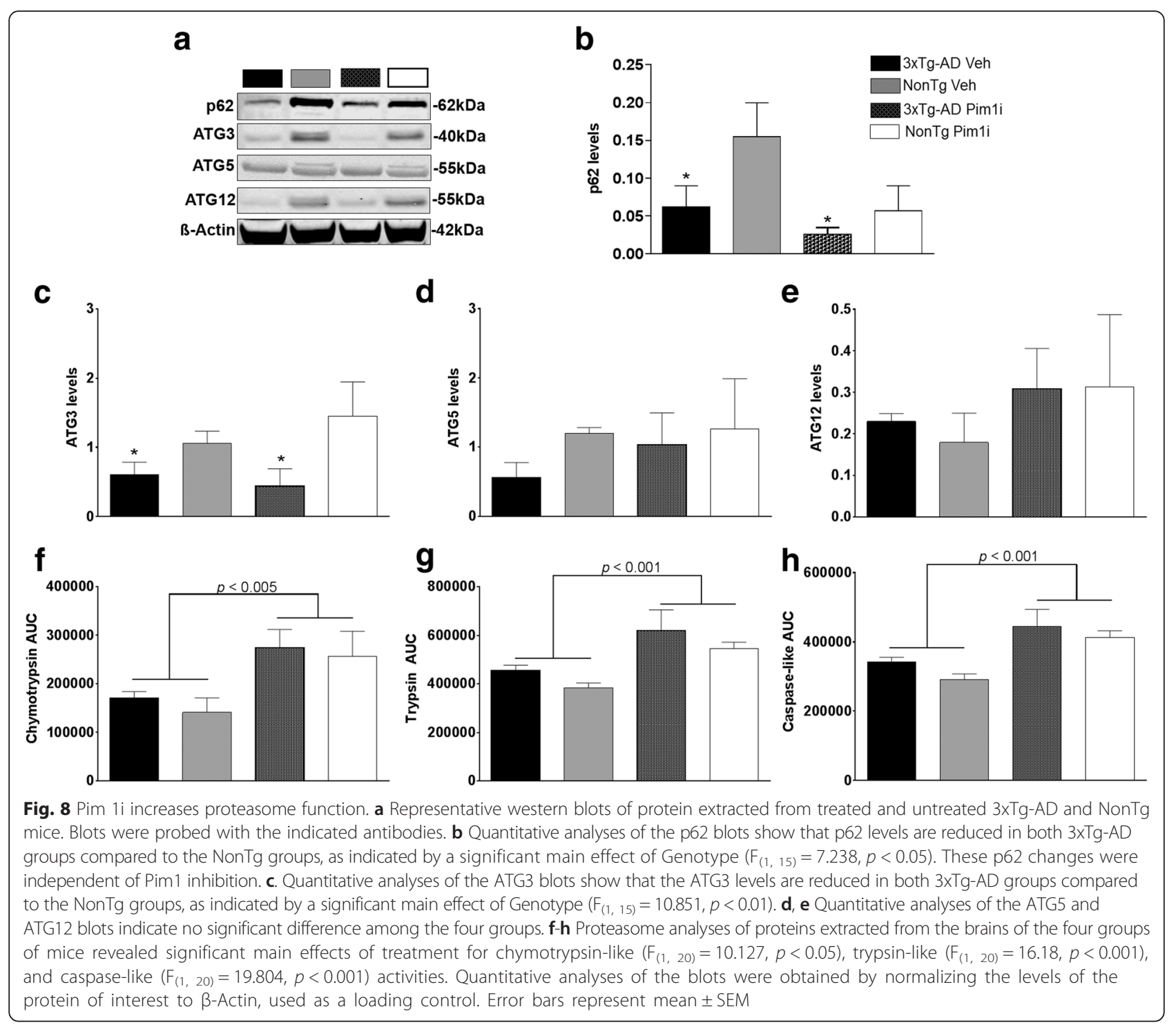

phosphorylation might represent a molecular link between diabetes and $\mathrm{AD}$.

\section{Conclusions}

In conclusion, our data highlight the commercially available Pim1 inhibitor as a potential therapeutic to reduced $\mathrm{AD}$-neuropathology and associated cognitive deficits by decreasing elevated pPRAS40 levels and increasing proteasome activity in the $3 \times \mathrm{Tg}$-AD mouse model.

\section{Methods}

Human and mouse tissue

Human tissue was obtained from the Brain and Body Donation Program at the Banner Sun Health Research Institute, an ongoing longitudinal clinicopathological study of normal aging and neurodegenerative disorders
[57]. Human cases were selected randomly by personnel of the Brain and Body Donation program among the tissue available. Groups were matched based on their clinical and neuropathological phenotype. The generation of the 3xTg-AD mice used in the current study has been described previously [34]. All mice were housed 4-5 per cage at $23{ }^{\circ} \mathrm{C}$, kept on a $12 \mathrm{~h}$ light/dark cycle, and were given ad libitum access to food and water. In our colony of 3xTg-AD mice, males show a large neuropathological variability, even between littermates. In contrast, female 3xTg-AD mice do not show such large variability and their phenotype changes as a function of age in a predictable manner. Therefore, only female mice were used for the experiments described here. All animal procedures were approved by the Arizona State University Institutional Animal Care and Use Committee (IACUC). All behavioral and experiments were performed 
with the experimenters blind to the genotype and treatment.

\section{Pim1i analysis}

Absorption Systems (Philadelphia, PA) performed the detection of the Pim1 inhibitor in the blood and brain of C57BL $/ 6$ mice injected with a dosage of $50 \mathrm{mg} / \mathrm{kg}$. Standards were prepared in C57BL/6 mouse plasma containing sodium heparin as an anticoagulant, or in blank homogenized C57BL/6 mouse brain. The calibration curve was prepared to concentrations of 1000, 500, 250, $100,50,10,5$, and $2.5 \mathrm{ng} / \mathrm{mL}$ by serial dilution. Standard samples were treated identically to the study samples. Plasma and brain homogenate samples were extracted via acetonitrile precipitation on a Tomtec Quadra 96Model 320 liquid handling system in a 96-well plate format. The procedure for sample extraction were as follows; (1) Add $55 \mu \mathrm{L}$ of samples or standards into $2 \mathrm{~mL}$ polypropylene 96-well plate; (2) Using the Tomtec, add $50 \mu \mathrm{L}$ of sample to $150 \mu \mathrm{L}$ of acetonitrile (containing $100 \mathrm{ng} / \mathrm{mL}$ warfarin as an internal standard) that has been pre-loaded onto a Sirocco Protein Precipitation plate (Waters Corp.); (3) Using the Tomtec, mix the samples via air aspiration; (4) Apply vacuum and Cap for analysis.

\section{8-arm radial arm water maze}

The radial arm water maze (RAWM) task is utilized to assess hippocampal-dependent spatial reference and working memory $[58,59]$. The task was performed in a black maze of $66 \mathrm{~cm}$ in diameter, made of black ABS Plexiglas. The maze consists of eight radiating arms, which were filled with water kept at $23.5{ }^{\circ} \mathrm{C}$. The water was made opaque with nontoxic white paint. An $8 \mathrm{~cm}$ wide platform was kept $1.5 \mathrm{~cm}$ under the surface of the water at the end of the arm and was invisible to mice. A white ABS pipe $2.5 \mathrm{~cm}$ wide and plastic flag were used for visible trials. The location of the extramazal cues and platform were kept in the same place in space throughout the testing period. Mice were tested between 9:00 A.M. and 3:00 P.M. and started from a different pseudorandomly chosen arm for each of the 15 daily trials. On the first trial of day one, mice were to locate the platform with the aid of a flag attached to the platform, making this trial visible. On trial 2 , the flag was removed, forcing the mice to use extramazal cues (located throughout the room) to find the escape platform. The proceeding trials alternated from visible to hidden until 12 trials were completed, followed by three hidden trials to end day one. On day two, mice received 15 trials, which were all performed with the hidden platform. If mice failed to find the platform within $60 \mathrm{~s}$, they were gently guided to the platform location and allowed to stay on it for $10 \mathrm{~s}$. At the end of each trial, mice were placed in a warm holding cage for $25 \mathrm{~s}$ before starting the next trial. A video camera recorded each mouse, and the experimenter, which was blind to the genotype and treatment scored the entries into arms. The dependent variables for learning were incorrect arm entries and reentries in day one versus two, with a decrease number of errors in day 2 versus day 1 interpreted as learning. The dependent measures for day 2 were incorrect arm entries (reference memory errors), reentries (working memory errors) and chaining events (3 consecutive arm entries into adjacent arms).

\section{Protein extraction}

Human and mouse proteins were prepared as previously described [10]. Briefly, mice were sacrificed and their brains were removed and cut in half along the medial longitudinal/sagittal fissure. One hemisphere of the brain was post-fixed in $4 \%$ paraformaldehyde for $48 \mathrm{~h}$ and used for immunohistochemical evaluation. The other hemisphere was flash-frozen on dry ice and used for biochemical experiments and stored at $-80{ }^{\circ} \mathrm{C}$. The frozen mouse hemispheres as well as $0.1 \mathrm{~g}$ of human inferior frontal gyrus tissue were mechanically homogenized in ice-cold T-PER protein extraction buffer (Thermo Fisher Scientific) containing complete protease inhibitor (Roche) and phosphatase inhibitor (Life Technologies). Brain homogenates were ultracentrifuged at 100,000 $\times \mathrm{g}$ for $1 \mathrm{~h}$ at $4{ }^{\circ} \mathrm{C}$. The supernatant was recovered and stored at $-80{ }^{\circ} \mathrm{C}$ until used for western blots and for both pPRAS40 and soluble A $\beta$ levels by ELISA. The pellet was re-suspended in $70 \%$ formic acid, mechanically homogenized, and centrifuged as described above. The supernatant of this second centrifugation was recovered and stored at $-80{ }^{\circ} \mathrm{C}$ until used as the insoluble fraction for ELISA experiments.

\section{Western blot}

Western blots were performed under reducing conditions using precast Novex gels (Life Technologies). Proteins were transferred to nitrocellulose membranes (iBlot2, Life Technologies) followed by incubation for $60 \mathrm{~min}$ in $5 \%$ nonfat powdered milk (Great Value) in Tris-buffered saline with Tween (TBST: $0.1 \mathrm{M}$ Tris, $0.15 \mathrm{M} \mathrm{NaCl}$, and $0.1 \%$ Tween 20). Primary antibodies specific to the experiment were then applied overnight at $4{ }^{\circ} \mathrm{C}$ in $5 \%$ milk in TBST. The following day, blots were washed in TBST three times for $15 \mathrm{~min}$ and then incubated in the appropriate fluorescent secondary antibody for $1 \mathrm{~h}$ at room temperature. The blots were then washed as describe above, and imaged/quantified using a LICOR Odyssey CLx (LI-COR Biosciences) attached to a Dell computer (OptiPlex 7010) running Windows 7 and Image Studio (version 1.0.11, LI-COR Biosciences). Quantitative analyses of the western blots were obtained 
by normalizing the intensity of the protein of interest with its loading control, $\beta$-actin.

\section{Histology}

For immunohistochemistry analysis, hemispheres were fixed in $4 \%$ paraformaldehyde for $48 \mathrm{~h}$. Tissue was then sectioned (50 $\mu \mathrm{m}$ thick) using a sliding vibratome, and stored in $0.02 \%$ sodium azide in PBS. The endogenous peroxidase activity was quenched with $3 \% \mathrm{H}_{2} \mathrm{O}_{2}$ in $10 \%$ methanol for 30 min. For $A \beta_{42}$ staining, tissue was incubated for $7 \mathrm{~min}$ in $95 \%$ formic acid to retrieve the epitope. Then, tissue was incubated overnight at $4{ }^{\circ} \mathrm{C}$ with an appropriate primary antibody. Sections were washed to remove excess primary antibody and incubated in the appropriate secondary antibody for $1 \mathrm{~h}$ at room temperature. Excess secondary antibody was washed and sections were developed with diaminobenzidine substrate using the avidin- biotin horseradish peroxidase system (Vector Labs).

\section{ELISA}

The commercially available sandwich ELISA assay by Cell Signaling Technology was used to assess pPRAS40 levels. Fractions of brain homogenates were processed and read in a plate reader (Bio Tek) at $450 \mathrm{~nm}$ in precoated, flat-bottom 96-well plates according to the kit's instructions. The concentration of pPRAS40 (picograms per milliliter of sample) present in the homogenate was the dependent variable used for statistical analysis. We used the Life Technologies ELISA kit to assess $A \beta_{40}$ and $A \beta_{42}$ levels. Briefly, soluble or insoluble fractions of brain tissue homogenates were processed and read in a plate reader (BioTek) at $450 \mathrm{~nm}$ in precoated, flatbottom 96-well plates according to the kit's instructions. The range of $A \beta$ detection was between 10 and $1000 \mathrm{pg} /$ $\mathrm{ml}$. For each assay kit, cross-reactivity with other species of $\mathrm{A} \beta$, APP, or tau was negligible when concentrations were $<10 \mathrm{ng} / \mathrm{ml}$. The concentration of $\mathrm{A} \beta$ (picograms per milliliter of sample) present in the homogenate was the dependent variable used for statistical analysis.

\section{Proteasome activity}

Proteasome activity was assessed as previously described [10]. Briefly, $10 \mu \mathrm{l}$ of brain homogenate were incubated with proteasomal substrates Suc-LLVY-AMC, Bz-VGRAMC, and Z-LLE-AMC (Enzo Life Sciences), which probe for chymotrypsin-like, trypsin-like, and caspaselike activities, respectively. Reactions were performed in $200 \mu \mathrm{l}$ of assay buffer ( $25 \mathrm{mM}$ HEPES, $\mathrm{pH} 7.5,0.5 \mathrm{mM}$ EDTA, $0.05 \%$ NP-40) using black 96-well plates. Substrates were added immediately before readings. Kinetic readings were taken at $37{ }^{\circ} \mathrm{C}$ every $1.5 \mathrm{~min}$ for $60 \mathrm{~min}$ (excitation, $360 \mathrm{~nm}$; emission, $460 \mathrm{~nm}$ ) using the Synergy HT multimode microplate reader with Gen5 software (BioTek). Readings were normalized to total protein concentrations assayed via a Coomassie Protein Assay Kit (Bradford, Thermo Scientific) following the manufacturer's instructions.

\section{Antibodies}

The following antibodies were purchased from Cell Signaling Technology: pP70S6K1 Thr389 (dilution 1:1000, catalog \#9204), p4EB-P1 Ser65 (dilution 1:1000, catalog \#9451) $\beta$-actin (dilution 1:10000, catalog \#3700), Atg3 (dilution 1:1000, catalog \#3415), Atg5 (dilution 1:1000, catalog \#2630), Atg12 (dilution 1:1000, catalog \#2010). The following antibodies were purchased from Millipore: anti-A $\beta_{42}$ (dilution 1:200, catalog \#AB5078P). Thermo Fisher Scientific provided HT7 (dilution 1:3000, catalog \#MN1000). CP13 (dilution 1:1000) was a gift from Peter Davies.

\section{Statistical analyses}

Examination of the data evaluated via mixed (repeated measures) model ANOVAs revealed no violations of any assumptions that would warrant using a statistical test other than the ones described. Assumptions were tested via conventional methods using SPSS 18 (IBM). These included normality (Shapiro-Wilk, p's 0.10), homogeneity of variance (Levene's test, p's 0.05 ), and sphericity (Mauchly's test, p's 0.26). Learning data which included incorrect (reference) errors and working memory errors were analyzed by a two-way mixed ANOVA, followed by Bonferroni's corrected post hoc tests using Statview for Windows Version 5.0.1. Chaining data were analyzed using a 2x2 contingency Chi-square table. Proteasome activity was analyzed by an omnibus two-way ANOVA. A two-tailed unpaired $t$ test was used to analyze select pairwise comparisons (e.g., Western blots in human cases and histology, ELISA for soluble and insoluble $A \beta$ in $3 \times T g-A D$ mice), as specified in the results section. These analyses were performed using Stat view for Windows Version 5.0.1. A priori power analysis was not performed but our sample sizes are similar to those reported in previously published papers (Ma et al., 2013; Caccamo et al., 2014; Caccamo et al., 2015). Where representative images are shown, statistical analyses were performed on the entire sample as indicated in each figure legend.

\section{Abbreviations}

AD, Alzheimer's disease; A $\beta$, amyloid beta; APP, amyloid precursor protein; BACE-1, beta-site APP-cleaving enzyme-1; ELISA, enzyme-linked immunosorbent assay; IRS-1, insulin-like growth factor 1; mTOR, mammalian target of rapamycin; mTORC1, mTOR complex 1; NFT, neurofibrillary tangles; PBS, phosphate buffer saline; p, phosphorylation; PRAS40, proline-rick Akt substrate 40 kDa; Pim 1, proto-oncogene serine/threonine-protein kinase Pim-1; RAWM, radial arm water maze; AKT, serine/threonine-specific protein kinase; TBST, tris-buffered saline with tween 


\section{Acknowledgements}

We thank Dr. Joshua Talboom with his help collecting the human data and Mr. Mario Moreno for his help imaging the tau histology slices. This work was supported by grants to S.O. from the National Institute on Aging (R01 AG037637) and the Alzheimer's Drug Discovery Foundation.

\section{Authors contributions}

RV carried out the dosing of the mice, the biochemical and histological experiments, analyzed the data and wrote the manuscript. DMS performed the behavioral experiments and contributed to drafting and revising/ reviewing the manuscript. AC participated in the design of the study, performed the proteasome and ELISA experiments, and contributed to drafting and revising/reviewing of the manuscript. SO designed the study, analyzed the data and wrote the manuscript.

All authors have read and approved the final version of the manuscript.

\section{Competing interests}

The authors have no competing interests in the manuscript.

Received: 18 February 2016 Accepted: 2 July 2016

Published online: 13 July 2016

\section{References}

1. LaFerla FM, Oddo S. Alzheimer's disease: Abeta, tau and synaptic dysfunction. Trends Mol Med. 2005;11:170-6.

2. Querfurth HW, LaFerla FM. Alzheimer's disease. N Engl J Med. 2010;362:329-44

3. Alzheimer's A. Alzheimer's disease facts and figures. Alzheimers Dement. 2015;2015(11):332-84

4. Moll L, El-Ami T, Cohen E. Selective manipulation of aging: a novel strategy for the treatment of neurodegenerative disorders. Swiss Med Wkly. 2014; 144:w13917.

5. Talboom JS, Velazquez R, Oddo S. The mammalian target of rapamycin at the crossroad between cognitive aging and Alzheimer's disease. NPJ Aging Mech Dis. 2015;1:15008.

6. Johnson SC, Rabinovitch PS, Kaeberlein M. mTOR is a key modulator of ageing and age-related disease. Nature. 2013;493:338-45.

7. Richardson A, Galvan V, Lin AL, Oddo S. How longevity research can lead to therapies for Alzheimer's disease: The rapamycin story. Exp Gerontol. 2015; 68:51-8.

8. Wullschleger $\mathrm{S}$, Loewith $\mathrm{R}$, Hall MN. TOR signaling in growth and metabolism. Cell. 2006;124:471-84.

9. Ma Y, Wu D, Zhang W, Liu J, Chen S, Hua B. Investigation of PI3K/PKB/ mTOR/S6K1 signaling pathway in relationship of type 2 diabetes and Alzheimer's disease. Int J Clin Exp Med. 2015;8:18581-90.

10. Caccamo A, Branca C, Talboom JS, Shaw DM, Turner D, Ma L, Messina A, Huang Z, Wu J, Oddo S. Reducing ribosomal protein S6 kinase 1 expression improves spatial memory and synaptic plasticity in a mouse model of Alzheimer's disease. J Neurosci. 2015;35:14042-56.

11. An WL, Cowburn RF, Li L, Braak H, Alafuzoff I, lqbal K, Iqbal IG, Winblad B, Pei JJ. Up-regulation of phosphorylated/activated p70 S6 kinase and its relationship to neurofibrillary pathology in Alzheimer's disease. Am J Pathol. 2003;163:591-607

12. Pei JJ, Bjorkdahl C, Zhang H, Zhou X, Winblad B. p70 S6 kinase and tau in Alzheimer's disease. J Alzheimers Dis. 2008;14:385-92.

13. Chang RC, Wong AK, Ng HK, Hugon J. Phosphorylation of eukaryotic initiation factor-2alpha (elF2alpha) is associated with neuronal degeneration in Alzheimer's disease. Neuroreport. 2002;13:2429-32.

14. Caccamo A, De Pinto V, Messina A, Branca C, Oddo S. Genetic reduction of mammalian target of rapamycin ameliorates Alzheimer's disease-like cognitive and pathological deficits by restoring hippocampal gene expression signature. J Neurosci. 2014;34:7988-98.

15. Caccamo A, Majumder S, Richardson A, Strong R, Oddo S. Molecular interplay between mammalian target of rapamycin (mTOR), amyloid-beta, and Tau: effects on cognitive impairments. J Biol Chem. 2010;285:13107-20.

16. Majumder S, Richardson A, Strong R, Oddo S. Inducing autophagy by rapamycin before, but not after, the formation of plaques and tangles ameliorates cognitive deficits. PLoS One. 2011;6:e25416.

17. Spilman P, Podlutskaya N, Hart MJ, Debnath J, Gorostiza O, Bredesen D, Richardson A, Strong R, Galvan V. Inhibition of mTOR by rapamycin abolishes cognitive deficits and reduces amyloid-beta levels in a mouse model of Alzheimer's disease. PLoS One. 2010;5:e9979.
18. Boers-Doets CB, Epstein JB, Raber-Durlacher JE, Ouwerkerk J, Logan RM, Brakenhoff JA, Lacouture ME, Gelderblom H. Oral adverse events associated with tyrosine kinase and mammalian target of rapamycin inhibitors in renal cell carcinoma: a structured literature review. Oncologist. 2012;17:135-44.

19. Hille U, Soergel P, Makowski L, Dork-Bousset T, Hillemanns P. Lymphedema of the breast as a symptom of internal diseases or side effect of mTor inhibitors. Lymphat Res Biol. 2012;10:63-73.

20. Ersoy A, Koca N. Everolimus-induced lymphedema in a renal transplant recipient: a case report. Exp Clin Transplant. 2012;10:296-8.

21. Sancak Y, Thoreen CC, Peterson TR, Lindquist RA, Kang SA, Spooner E, Carr SA, Sabatini DM. PRAS40 is an insulin-regulated inhibitor of the mTORC protein kinase. Mol Cell. 2007;25:903-15.

22. Wang L, Harris TE, Roth RA, Lawrence Jr JC. PRAS40 regulates mTORC1 kinase activity by functioning as a direct inhibitor of substrate binding. J Biol Chem. 2007;282:20036-44.

23. Caccamo A, Maldonado MA, Majumder S, Medina DX, Holbein W, Magri A Oddo S. Naturally secreted amyloid-beta increases mammalian target of rapamycin (mTOR) activity via a PRAS40-mediated mechanism. J Biol Chem. 2011:286:8924-32

24. Cuypers HT, Selten G, Quint W, Zijlstra M, Maandag ER, Boelens W, van Wezenbeek P, Melief C, Berns A. Murine leukemia virus-induced T-cell lymphomagenesis: integration of proviruses in a distinct chromosomal region. Cell. 1984;37:141-50.

25. Hoover D, Friedmann M, Reeves R, Magnuson NS. Recombinant human pim-1 protein exhibits serine/threonine kinase activity. J Biol Chem. 1991;266:14018-23.

26. Saris CJ, Domen J, Berns A. The pim-1 oncogene encodes two related protein-serine/threonine kinases by alternative initiation at AUG and CUG. EMBO J. 1991;10:655-64.

27. van der Lugt NM, Domen J, Verhoeven E, Linders K, van der Gulden H, Allen J, Berns A. Proviral tagging in E mu-myc transgenic mice lacking the Pim-1 proto-oncogene leads to compensatory activation of Pim-2. EMBO J. 1995; 14:2536-44.

28. Amson R, Sigaux F, Przedborski S, Flandrin G, Givol D, Telerman A. The human protooncogene product p33pim is expressed during fetal hematopoiesis and in diverse leukemias. Proc Natl Acad Sci U S A. 1989:86:8857-61.

29. van Lohuizen M, Verbeek S, Krimpenfort P, Domen J, Saris C, Radaszkiewicz $\mathrm{T}$, Berns A. Predisposition to lymphomagenesis in pim-1 transgenic mice: cooperation with c-myc and $\mathrm{N}$-myc in murine leukemia virus-induced tumors. Cell. 1989;56:673-82.

30. Laird PW, van der Lugt NM, Clarke A, Domen J, Linders K, McWhir J, Berns A, Hooper M. In vivo analysis of Pim-1 deficiency. Nucleic Acids Res. 1993:21:4750-5.

31. Jacobs MD, Black J, Futer O, Swenson L, Hare B, Fleming M, Saxena K. Pim-1 ligand-bound structures reveal the mechanism of serine/threonine kinase inhibition by LY294002. J Biol Chem. 2005;280:13728-34.

32. Kumar JK, Ping RY, Teong HF, Goh S, Clement MV. Activation of a non-genomic Pim-1/Bad-Pser75 module is required for an efficient pro-survival effect of BCl-xL induced by androgen in LNCaP cells. Int J Biochem Cell Biol. 2011:43:594-603.

33. Zhang F, Beharry ZM, Harris TE, Lilly MB, Smith CD, Mahajan S, Kraft AS. PIM1 protein kinase regulates PRAS40 phosphorylation and mTOR activity in FDCP1 cells. Cancer Biol Ther. 2009;8:846-53.

34. Oddo S, Caccamo A, Shepherd JD, Murphy MP, Golde TE, Kayed R, Metherate R, Mattson MP, Akbari Y, LaFerla FM. Triple-transgenic model of Alzheimer's disease with plaques and tangles: intracellular Abeta and synaptic dysfunction. Neuron. 2003;39:409-21.

35. Lovasic L, Bauschke $H$, Janus $C$. Working memory impairment in a transgenic amyloid precursor protein TgCRND8 mouse model of Alzheimer's disease. Genes Brain Behav. 2005;4:197-208.

36. Vilchez D, Saez I, Dillin A. The role of protein clearance mechanisms in organismal ageing and age-related diseases. Nat Commun. 2014:5:5659.

37. Mizushima N. Methods for monitoring autophagy. Int J Biochem Cell Biol. 2004;36:2491-502

38. Craiu A, Gaczynska M, Akopian T, Gramm CF, Fenteany G, Goldberg AL, Rock KL. Lactacystin and clasto-lactacystin beta-lactone modify multiple proteasome beta-subunits and inhibit intracellular protein degradation and major histocompatibility complex class I antigen presentation. J Biol Chem. 1997;272:13437-45.

39. Heinemeyer $W$, Fischer $M$, Krimmer $T$, Stachon $U$, Wolf DH. The active sites of the eukaryotic $20 \mathrm{~S}$ proteasome and their involvement in subunit precursor processing. J Biol Chem. 1997;272:25200-9. 
40. Layfield R, Cavey JR, Lowe J. Role of ubiquitin-mediated proteolysis in the pathogenesis of neurodegenerative disorders. Ageing Res Rev. 2003;2:343-56,

41. Wiza C, Chadt A, Blumensatt M, Kanzleiter T, Herzfeld De Wiza D, Horrighs A, Mueller $\mathrm{H}$, Nascimento EB, Schurmann A, Al-Hasani H, Ouwens DM. Over-expression of PRAS40 enhances insulin sensitivity in skeletal muscle. Arch Physiol Biochem. 2014;120:64-72.

42. Wiza C, De Wiza Herzfeld D, Nascimento EB, Lehr S, Al-Hasani H, Ouwens DM. Knockdown of PRAS40 inhibits insulin action via proteasome-mediated degradation of IRS1 in primary human skeletal muscle cells. Diabetologia. 2013;56:1118-28.

43. Keller JN, Hanni KB, Markesbery WR. Impaired proteasome function in Alzheimer's disease. J Neurochem. 2000;75:436-9.

44. Oddo S. The ubiquitin-proteasome system in Alzheimer's disease. J Cell Mol Med. 2008;12:363-73.

45. Tseng BP, Green KN, Chan JL, Blurton-Jones M, LaFerla FM. Abeta inhibits the proteasome and enhances amyloid and tau accumulation. Neurobiol Aging. 2008;29:1607-18.

46. Hong L, Huang HC, Jiang ZF. Relationship between amyloid-beta and the ubiquitin-proteasome system in Alzheimer's disease. Neurol Res. 2014;36: 276-82.

47. Medina DX, Caccamo A, Oddo S. Methylene blue reduces abeta levels and rescues early cognitive deficit by increasing proteasome activity. Brain Pathol. 2011;21:140-9.

48. Leibson CL, Rocca WA, Hanson VA, Cha R, Kokmen E, O'Brien PC, Palumbo PJ. The risk of dementia among persons with diabetes mellitus: a population-based cohort study. Ann N Y Acad Sci. 1997:826:422-7.

49. Ott A, Stolk RP, van Harskamp F, Pols HA, Hofman A, Breteler MM. Diabetes mellitus and the risk of dementia: the Rotterdam study. Neurology. 1999;53:1937-42.

50. Qiu CX, Winblad B, Fratiglioni L. Risk factors for dementia and Alzheimer's disease-findings from a community-based cohort study in Stockholm, Sweden. Zhonghua Liu Xing Bing Xue Za Zhi. 2005;26:882-7.

51. Wang YF, Khan M, van den Berg HA. Interaction of fast and slow dynamics in endocrine control systems with an application to beta-cell dynamics. Math Biosci. 2012;235:8-18

52. Wang H, Zhang $Q$, Wen $Q$, Zheng Y, Lazarovici P, Jiang H, Lin J, Zheng W. Proline-rich Akt substrate of $40 \mathrm{kDa}$ (PRAS40): a novel downstream target of PI3K/Akt signaling pathway. Cell Signal. 2012;24:17-24.

53. Vander Haar E, Lee SI, Bandhakavi S, Griffin TJ, Kim DH. Insulin signalling to mTOR mediated by the Akt/PKB substrate PRAS40. Nat Cell Biol. 2007;9:316-23.

54. Nascimento EB, Fodor $M$, van der Zon GC, Jazet IM, Meinders AE, Voshol PJ, Vlasblom R, Baan B, Eckel J, Maassen JA, et al. Insulin-mediated phosphorylation of the proline-rich Akt substrate PRAS40 is impaired in insulin target tissues of high-fat diet-fed rats. Diabetes. 2006;55:3221-8.

55. Dey N, Ghosh-Choudhury N, Das F, Li X, Venkatesan B, Barnes JL, Kasinath BS, Ghosh Choudhury G. PRAS40 acts as a nodal regulator of high glucoseinduced TORC1 activation in glomerular mesangial cell hypertrophy. J Cell Physiol. 2010;225:27-41.

56. Yates SC, Zafar A, Hubbard P, Nagy S, Durant S, Bicknell R, Wilcock G, Christie S, Esiri MM, Smith AD, Nagy Z. Dysfunction of the mTOR pathway is a risk factor for Alzheimer's disease. Acta Neuropathol Commun. 2013;1:3.

57. Beach TG, Sue LI, Walker DG, Roher AE, Lue L, Vedders L, Connor DJ, Sabbagh MN, Rogers J. The Sun Health Research Institute Brain Donation Program: description and experience, 1987-2007. Cell Tissue Bank. 2008; 9:229-45.

58. Alamed J, Wilcock DM, Diamond DM, Gordon MN, Morgan D. Two-day radial-arm water maze learning and memory task; robust resolution of amyloid-related memory deficits in transgenic mice. Nat Protoc. 2006;1: $1671-9$

59. Penley SC, Gaudet CM, Threlkeld SW. Use of an eight-arm radial water maze to assess working and reference memory following neonatal brain injury. Journal of visualized experiments: JoVE. 2013:50940.

\section{Submit your next manuscript to BioMed Central and we will help you at every step:}

- We accept pre-submission inquiries

- Our selector tool helps you to find the most relevant journal

- We provide round the clock customer support

- Convenient online submission

- Thorough peer review

- Inclusion in PubMed and all major indexing services

- Maximum visibility for your research

Submit your manuscript at www.biomedcentral.com/submit
Biomed Central 